International

Medical Society

http://imedicalsociety.org

\title{
The Reality of Tuberculosis in Brazilian Prisons
}

ORIGINAL

Mayara Lima Barbosa ${ }^{1}$, Hayla Nathália dos Santos Rodrigues ${ }^{2}$, Suely Deysny de Matos Celino ${ }^{3}$, Tarciana Nobre de Menezes ${ }^{4}$, Karla Karolline Barreto Cardins ${ }^{5}$, Gabriela Maria Cavalcanti Costa ${ }^{6}$

\section{Abstract}

Objective: This work aims to identify the profile of morbidity due to TB in prisons among the regions of Brazil, from 2003 to 2012.

Methods: This is an epidemiological and retrospective study in which the data were obtained through the virtual query to the database of the Notification Diseases Information System, through DATASUS portal and were tabulated and analyzed according to descriptive statistics. The numbers of cases of TB were organized respecting the years that make up the study and the region.

Results: During the survey period there were reported 30,662 cases of TB in Brazilian prisons. The profile of TB in Brazilian prisons is made up of men, brown, allocated in the Southeast, with the pulmonary form of the disease, who are not HIV positive and who perform supervised treatment. It was also found that less than half of the cases had the cure varies as the situation of closure.

\section{Keywords}

Prisons; Communicable Diseases; Tuberculosis; Temporal Distribution;

Descriptive Epidemiology.

\section{Introduction}

In Brazil, according to the Notification Diseases Information System (NDIS), in 2013 there were registered 81,825 cases of tuberculosis (TB). Although this number present $4 \%$ decrease from the previous year, it still appears to be significant and worthy of attention, being considered a public health problem [1].

Faced with the worrying scenario that the general population is, it is a condition sine que non to consider individuals who are in the prison
1 Nurse. Master in Public Health, State University of Paraíba. Student of Nursing Doctoral course. Federal University of Rio Grande do Norte/ UFRN. Natal(RN), Brazil.

2 Nurse. State University of Paraíba. Campina Grande (PB), Brazil.

3 Nurse. Master in Public Health. State University of Paraíba. Professor of nursing graduation, Faculty of Medical Sciences of Campina Grande. Campina Grande (PB), Brazil.

4 Nutritionist. Ph.D. in Public health. University of Sao Paulo. Professor of the Graduate Program in Saúde pública, State University of Paraíba. Campina Grande (PB), Brazil.

5 Nurse. Master's student in public health, State University of Paraíba. Campina Grande (PB), Brazil.

6 Nurse. Ph.D. in Nursing. University of Sao Paulo. Professor of the Graduate Program in Saúde pública, State University of Paraíba. Campina Grande (PB), Brazil.

\section{Contact information:}

\section{Mayara Lima Barbosa.}

Address: Rua Santo Antonio, 90, apto 303, Santo Antonio, Campina Grande, Paraíba, Brasil.

Tel: 83 99623-3118.

Đmay.lb@hotmail.com 
environment. This fact is justified by the majority of the environment of Brazilian prisons, characterized by agglomeration of individuals, precarious infrastructure and closed local, with shortages of air circulation. This situation facilitates the spread of tuberculosis (TB), in order that the saliva droplets contaminated with the bacillus remain in place for a broad time interval, infecting a large number of people. There is still a high incidence of infectious diseases and drug abuse [2].

These factors provide an increase of TB cases in prisons. According to a study conducted in the state prisons of Espirito Santo, the incidence of TB was found to be approximately 62 times higher than the state rate and 55 times higher than the national compared to the general population [3].

Faced with this scenario, significant investments have been made aimed at prevention and treatment of tuberculosis, such as the creation and steady expansion of the National Program for Tuberculosis Control (NPTC) [2]. In the prison system, the National Policy for Integral Health Care of Persons Deprived of Liberty in Prisons (NPIHHP) provides for the implementation of actions for disease prevention and health promotion at the basic level of attention to the prisoners. For tuberculosis control, activities should strive for search cases by identifying patients after conducting the appropriate tests and treatment after the inclusion of the imprisoned in the national register [4].

There is scarce number of publications on prison health, especially those who are able to address large time scales and contribute to the knowledge about the health of the prison population after 12 years of publication of the National Health of Prisons Plan(NHPP) and two years of the publication of NPIHHP, with emphasis on TB control activities in the prison environment. In this way, this study aims identifying the profile of morbidity due to TB in prisons among the regions of Brazil from 2003 until 2012.

\section{Methods}

To welcome the proposal of the study it was held an epidemiological retrospective study called historical or time series. Data were obtained through virtual consultation with the SINAN database, through DATASUS portal.

The study population consists in confirmed cases according to the year of diagnosis, the country of notification and institutionalization in Brazilian prisons in the period from January 2003 to December 2012. Study variables were: diagnosed cases, treated cases, TB cases according to the shape, skin color, sex, presence or absence of AIDS, indication and / or completion of the supervised treatment and closing situation. In order to avoid mistakes regarding the notification delay, it was decided to analyze the data available until 2012.

The computer program called TabWin was used in order to operationalize the exploration of databases. This instrument was developed by the Ministry of Health with free and open dissemination. The numbers of cases of TB were organized respecting the years that make up the study and the region. Subsequently, descriptive statistics were performed using SPSS version 21.0.

Because it is a public domain database, it was not necessary to submit the project to the Research Ethics Committee.

\section{Results}

Figure 1 shows the number of TB cases diagnosed per year in Brazil from 2003 to 2012. It was observed the growing trend in the time series, except for the year 2010 that interrupts the continuous ascendance, with a small reduction compared to cases diagnosed in the previous year, 2009. It is still important to note the significant increase between 2007 and 2008.

In the period between 2003 and 2012 were reported in the SINAN database 30,662 diagnosed cases of TB in Brazilian prisons. Table 1 shows 


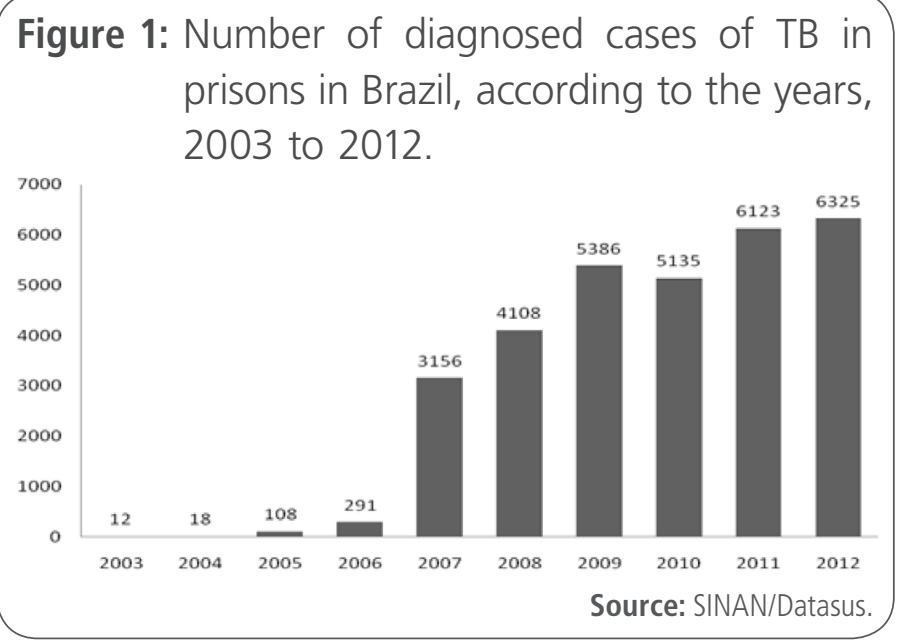

the distribution of the number of cases of TB in prisons according to sex, skin color and the country region.

It is observed that the Southeast has more cases of TB in prisons (47.95\%), followed by the Northeast (20.94\%), South (19.73\%), Central West (6.49\%) and North (4.89\%). For cases of TB and sex of the convict, the rates are higher in males (90.98\%) over females (9.02\%). TB cases are more present in convicts who declared themselves brown, corresponding to $36.08 \%$, followed by blacks (33.69\%) and whites $(16.23 \%)$

Table 1. Distribution of cases of TB in prisons according to gender and skin color in the states and the Federal District, 2003-2012.

\begin{tabular}{|c|c|c|c|c|c|c|c|}
\hline \multirow{2}{*}{$\begin{array}{c}\text { State or Federal } \\
\text { District }\end{array}$} & \multirow{2}{*}{$\begin{array}{l}\text { Diagnosed } \\
\text { cases }\end{array}$} & \multicolumn{2}{|c|}{ Sex * } & \multicolumn{4}{|c|}{ Skin color ** } \\
\hline & & Male & Female & Brown & White & Black & Others \\
\hline \multicolumn{8}{|l|}{ Brazil } \\
\hline N & 30.662 & 27.749 & 2.751 & 11.426 & 5.139 & 10.668 & 4.433 \\
\hline$\%$ & 100.00 & 90.98 & 9.02 & 36.08 & 16.23 & 33.69 & 14.00 \\
\hline \multicolumn{8}{|l|}{ North } \\
\hline N & 1499 & 1296 & 203 & 1053 & 1152 & 219 & 76 \\
\hline$\%$ & 4.89 & 4.25 & 0.67 & 3.33 & 3.64 & 0.69 & 0.24 \\
\hline \multicolumn{8}{|l|}{ Northeast } \\
\hline N & 6.421 & 5.581 & 847 & 3.827 & 809 & 925 & 873 \\
\hline$\%$ & 20.94 & 18.30 & 2.78 & 12.09 & 2.55 & 2.92 & 2.76 \\
\hline \multicolumn{8}{|l|}{ Midwest } \\
\hline N & 1990 & 1773 & 217 & 997 & 182 & 574 & 238 \\
\hline$\%$ & 6.49 & 5.81 & 0.71 & 3.15 & 0.57 & 1.81 & 0.75 \\
\hline \multicolumn{8}{|l|}{ Southeast } \\
\hline N & 14.701 & 13.608 & 925 & 4.889 & 2.092 & 4.839 & 2.871 \\
\hline$\%$ & 47.95 & 44.62 & 3.03 & 15.44 & 6.61 & 15.28 & 9.07 \\
\hline \multicolumn{8}{|l|}{ South } \\
\hline N & 6.051 & 5.491 & 559 & 660 & 904 & 4.111 & 375 \\
\hline$\%$ & 19.73 & 18.00 & 1.83 & 2.08 & 2.85 & 12.98 & 1.18 \\
\hline
\end{tabular}

Table 2 reports on cases of TB related to AIDS, the type of $T B$, the outcome of the case and the administration of the drug dose for the treatment of supervised manner. Among the cases of TB in prisons, $12.47 \%$ of inmates had AIDS, while $87.53 \%$ were negative cases. There is a superiority in the manifestation of pulmonary TB in relation to other forms, with 27,706 (90.84\%) reported cases. Regarding the variable outcome of the case, it is important that the outcome obtained other predominance, with $47.36 \%$, followed by healing with $44.42 \%$ of TB cases, abandonment of treatment $(6.98 \%)$ and death (1.24\%). It can be seen that in all Brazilian regions TB cases indicated for su- 
Table 2. Distribution of cases of TB in prisons according to diagnosis of AIDS and TB form of manifestation in the states and the Federal District, 2002 a 2013.

\begin{tabular}{|c|c|c|c|c|c|c|c|c|c|c|c|}
\hline \multirow{2}{*}{ 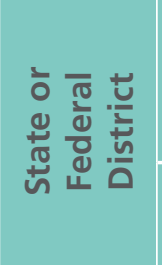 } & \multicolumn{2}{|c|}{ AIDS * } & \multirow{2}{*}{$\begin{array}{l}\frac{\lambda}{\sigma} \\
\frac{0}{0} * \\
\underbrace{*}_{\bar{E}}\end{array}$} & \multirow{2}{*}{ 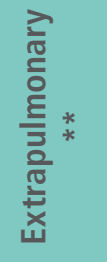 } & \multirow{2}{*}{ 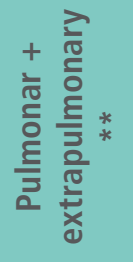 } & \multirow{2}{*}{ 竎 * * * } & \multirow{2}{*}{ 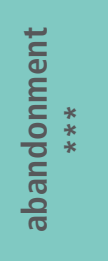 } & \multirow{2}{*}{ 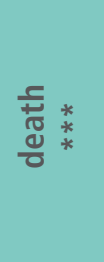 } & \multirow{2}{*}{ 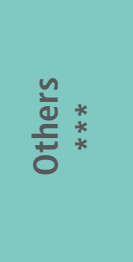 } & \multicolumn{2}{|c|}{$\begin{array}{c}\text { Tratamento } \\
\text { Supervisionado }\end{array}$} \\
\hline & $(+)$ & $(-)$ & & & & & & & & indicated & accomplished \\
\hline \multicolumn{12}{|l|}{ Brazil } \\
\hline$N$ & 2.848 & 19.999 & 27.706 & 2.072 & 723 & 13.574 & 2.133 & 379 & 14.474 & \multirow{2}{*}{30661} & \multirow{2}{*}{30661} \\
\hline$\%$ & 12.47 & 87.53 & 90.84 & 6.79 & 2.37 & 44.42 & 6.98 & 1.24 & 47.36 & & \\
\hline \multicolumn{12}{|l|}{ North } \\
\hline$N$ & 94 & 949 & 1352 & 111 & 37 & 643 & 161 & 12 & 554 & 1370 & 1.370 \\
\hline$\%$ & 0.41 & 4.15 & 4.55 & 0.37 & 0.12 & 2.10 & 0.53 & 0.04 & 1.81 & 4.48 & 4.48 \\
\hline \multicolumn{12}{|l|}{ Northeast } \\
\hline$N$ & 350 & 4.008 & 5.728 & 394 & 106 & 2.909 & 425 & 109 & 2.978 & 6.421 & 6.421 \\
\hline$\%$ & 1.53 & 17.54 & 19.28 & 1.33 & 0.36 & 9.52 & 1.39 & 0.36 & 9.74 & 21.01 & 21.01 \\
\hline \multicolumn{12}{|l|}{ Midwest } \\
\hline $\mathrm{N}$ & 176 & 1133 & 2.713 & 278 & 89 & 846 & 138 & 34 & 973 & 1.991 & 1.991 \\
\hline$\%$ & 0.77 & 4.96 & 9.13 & 0.94 & 0.30 & 2.77 & 0.45 & 0.11 & 3.18 & 6.52 & 6.52 \\
\hline \multicolumn{12}{|l|}{ Southeast } \\
\hline$N$ & 1216 & 10.376 & 16.232 & 1099 & 408 & 6.404 & 809 & 117 & 7.371 & 14.701 & 14.701 \\
\hline$\%$ & 5.32 & 45.42 & 54.65 & 3.70 & 1.37 & 20.96 & 2.65 & 0.38 & 24.12 & 48.11 & 48.11 \\
\hline \multicolumn{12}{|l|}{ South } \\
\hline $\mathrm{N}$ & 1012 & 3.533 & 975 & 118 & 64 & 2.772 & 600 & 107 & 2598 & 6.077 & 6.077 \\
\hline$\%$ & 4.43 & 15.46 & 3.28 & 0.40 & 0.22 & 9.07 & 1.96 & 0.35 & 8.50 & 19.89 & 19.89 \\
\hline
\end{tabular}

Source: SINAN/Datasus. *: $N=322.847, * *: N=30501, * * *: N=30.560$

pervised treatment were well conducted, totaling 30,661 treatments performed during the years selected for this study.

\section{Discussion}

The high number of TB diagnostic cases in prisons, observed in this study is related to the high transmissibility of $T B$, which is enhanced in prison scenarios due to several factors, which are related to convicts, such as drug use, low educational level and income [3], and the institution, as overcrowding, which discourages air circulation and makes poor the health assistance. In this way, it is possible to identify that this scenario requires specific attention to address the still present gaps and minimize the occurrence of damage to health.
In order to improve the TB notification arising from Brazilian prisons, since 2008 information about institutionalization, present in the compulsory notification form, also started to adopt prison origin [5]. This change increased the quality of notifications, making them more sensitive and therefore more cases of TB were reported and are available for consultation in the SINAN.

In addition to advances generated in compulsory notification form, in the period between 2003 and 2006 the Health Care Teams in Prisons (HCTP) were being deployed in the states already qualified to develop PNSSP. Official data show that in 2003 the number of EPEN across the country was 75 and in 2006 that number doubled, assuming a value greater than 150 EPEN throughout Brazil [5]. The largest contingent of health workers in Brazilian pri- 
sons enables better health care, as a result, the diagnosis of TB becomes more sensitive, the treatment can be properly conducted and the notifications to the information systems are carried out effectively.

From the cases reported in the information system, it was observed that the highest percentage of TB cases in prisons was among men. Several studies in the literature also point to the prevalence of TB cases among males. Both the prison population and the general population, men have higher TB rates in all age groups, when compared to women $[3,6]$.

The superiority of TB cases in males may be related to behavioral factors of men, by gender have lower levels of care with their health, compared to females, and access to health services is delayed, as well as health promotion, disease prevention, diagnosis and treatment of health aggravations [7].

Still, the high rates of TB found in men that may be related to different lifestyles adopted between the sexes, such as using higher tobacco, alcohol and drugs among men [8]. It is known that there are biological explanations to justify the difference in the rate of TB for the sexes, thus, cultural, social and health care factors are responsible for ensuring the differences presented between the sexes [9].

Another aspect observed in this study was a higher percentage of TB cases related to convicts who considered themselves mulattos. A study on TB held in a prison, between 2003 and 2006, also pointed out that the self-reported browns were more predominant in the notifications, followed by white self-reported [10]. It is noticed also that a lower percentage of inmates with TB had a positive diagnosis for AIDS, compared to negative diagnosis.

Also, in research conducted in the State of Rio Grande do Sul, using SINAN data, TB cases confirmed with seronegative predominated over the positive [10]. Thus, the chances of cure for these people is even greater, given that the Acquired Immunodeficiency Syndrome affects the immune system of the individual, making it more susceptible to illness from "opportunistic" diseases [11].
The PNAISP provides that should be carried out anti-HIV serology tests for all TB cases diagnosed or suspected, from the risk history or associated clinical manifestations [4]. This action aims to provide rapid treatment for all diagnosed cases in order to minimize the spread in the prison context.

The Ministry of Health recommends that the convict who has symptoms of pulmonary TB should remain in a specific room, in order to perform the respiratory isolation through examinations the diagnosis is confirmed and notified to give early treatment [3]. In this study, regarding diagnosed forms of TB, it was observed that the most common was the lung, corroborating with literature data, which presents the pulmonary form as the most prevalent compared to extrapulmonary [3, 12-13] and warning of the need for compliance with the basic guidelines of the Ministry of Health.

However, most of the prisons do not meet the basic guidelines for TB control. It is observed that the test is not performed for the disease diagnosis at admission of the detainee, in this way, by the living conditions prior to the arrest, many inmates entering the prison system is already infected with the Koch bacillus, spreading the disease among other convicts, since the drug treatment is not performed [14].

In order to increase the effectiveness of TB treatment can be indicated supervised treatment, consisting of a health care professional administer and observe the patient to ingest medicines. This oversight increases healing, decreases drug resistance and reduces cases of abandonment. In addition, monitoring of treatment should be done through its own records [15].

In TB cases in Brazilian prisons of qualified states that already have the EPEN, supervised treatment is prescribed for all diagnosed cases [4]. However, studies have observed that most of the implanted EPEN not have full composition related to professional categories, which may negatively impact on the effectiveness of supervised treatment for TB [16-17]. 
When we investigated the causes of closure of TB cases, found in this study that the cases of death were lower than the other variables analyzed. This information corroborates with the results of a study in the prisons of the State of Espirito Santo [3]. The death from TB usually occurs when there is no diagnosis and treatment, or even related to AIDS patients who abandoned treatment [18].

Another aspect very important for the low mortality among people with TB concerns the investment made by the state regarding the treatment, because funding for standard TB treatment in prison is the responsibility of government, and the distribution of free therapeutic is one criterion for facilitating adherence to treatment [4].

\section{Conclusions}

The inclusion of institutionalized category in the compulsory notification form should be considered a milestone in the record of the disease in the information system. The information generated is able to contribute with the planning of health actions for the prison system, especially for those diseases most incident among this population.

Failures in fulfilling the compulsory notification forms and underreporting, especially in prisons where there is no presence of the health team, was a limitation of this study. Therefore, it is important to emphasize the need for raising awareness among health professionals about the correct and complete filling of notifications forms, making the information systems in health even more reliable, and therefore able to provide real benefits for policy of health.

The TB profile in Brazilian prisons is formed by men, mulattos, who fulfilled sentence mainly in the Southeast Region, presented the pulmonary form of the disease. There are not AIDS patients and perform supervised treatment.

Finally, this work may contribute to understanding TB phenomenon in the Brazilian prison system, while exposing the TB profile, providing theoretical and scientific basis for what health promotion, TB prevention and clinical care can be directed to the most vulnerable public.

\section{References}

1. Ministério da Saúde [Brasil]. Manual de recomendações para o controle da tuberculose no Brasil. Brasília (DF), 2011. Available from: $\quad$ http://www.cve.saude.sp.gov.br/htm/TB/mat tec/ manuais/MS11_Manual_Recom.pdf. Acesso em: 20 nov. 2016

2. Teixeira EC, Costa JS. O impacto das condições de vida e da educação sobre a incidência de tuberculose no Brasil. Rev. Econ [Internet]. 2011 [cited 2016 Nov 21]; 37 (2): 106-123. Available from: $\quad$ http://ojs.c3sl.ufpr.br/ojs/index.php/economia/article/ viewFile/27241/18147.

3. Macedo LR, Macedo CR, Maciel ELN. Vigilância epidemiológica da tuberculose em presídios do Espírito Santo. Rev. Bras. Promo Saúde [Internet]. 2013 [cited 2016 Nov 21]; 26 (2): 216-222. Available from: <http://ojs.unifor.br/index.php/RBPS/article/ view/2907>.

4. Ministério da Saúde [Brasil]. Portaria Interministerial $n^{\circ} 1$, de 2 de janeiro de 2014. Institui a Política Nacional de Atenção Integral à Saúde das Pessoas Privadas de Liberdade no Sistema Prisional (PNAISP) no âmbito do Sistema Único de Saúde (SUS). Diário Oficial da União 02 jan 2014.

5. Ministério da Saúde [Brasil]. Secretaria de Atenção em Saúde. Legislação em Saúde no Sistema Penitenciário. Brasília (DF): MS; 2010.

6. Silva DC, Weiller TH, Farão EMD. Descrição de casos de tuberculose em pessoas institucionalizadas. Revista Contexto \& Saúde [Internet]. 2013 [cited 2016 Nov 21]; 10(20):893-898. Available from: https://www.revistas.unijui.edu.br/index.php/ contextoesaude/article/view/1688/1400

7. Belo MTCT. et al. Tuberculose e gênero em um município prioritário no estado do Rio de Janeiro. Jor Bras Pneumol. [Internet]. 2010 [cited 2016 Nov 21];36(5): 621-625, Available from: < http://www.scielo.br/pdf/jbpneu/v36n5/v36n5a15.pdf>

8. Araujo KMFA et al . Evolução da distribuição espacial dos casos novos de tuberculose no município de Patos (PB), 20012010. Cad. saúde colet [Internet]. 2013 [cited 2016 Nov 21]; 21( 3 ): 296-302. Available from: <http://www.scielo.br/scielo. php?script=sci arttext\&pid=S1414-462X2013000300010>

9. Hino P, Takahashi RF, Bertolozzi MR, Egry EY. A ocorrência da tuberculose em um distrito administrativo do município de São Paulo. Esc Anna Nery [Internet]. 2013 [cited 2016 Nov 21]; 17(1):153-159. Available from: <http://www.scielo.br/scielo. php?script=sci_arttext\&pid=S1414-81452013000100021 $>$. 
10. Moreira RM, Fávero JL, Maciel ELN. Tuberculose no sistema prisional capixaba. Rev. Bras. Pesq Saúde [Internet]. 2010 [cited 2016 Nov 21]; 12 (1): 26-33. Available from: <http://periodicos. ufes.br/RBPS/article/view/281>

11. Gouveia GPM, Gouveia SSV, Bezerra Filho JG, de Oliveira JBB. Estudo epidemiológico da tuberculose pulmonar no hospital penitenciário e sanatório professor otávio lobo no período de 2001-2006. Rev. Baiana Saúde Pública [Internet]. 2011 [cited 2016 Nov 21]; 34 (3): p.602-611. Available from: <http://inseer. ibict.br/rbsp/index.php/rbsp/article/viewFile/59/58>

12. De Oliveira HB, Cardoso JC. Tuberculose no sistema prisional de Campinas, São Paulo, Brasil. Rev Panam Salud Publica [Internet]. 2004 [cited 2016 Nov 21]; 15 (3): 195. Available from:

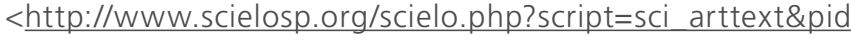
$=\$ 1020-49892004000300008>$.

13. Da Silva DC, Weiller TH, Farão EMD. Descrição de casos de tuberculose em pessoas institucionalizadas. Rev. Contexto \& Saúde [Internet]. 2013 [cited 2016 Nov 21]; 11 (20): 893-898. Available from: <https://www.revistas.unijui.edu.br/index.php/ contextoesaude/article/view/1688/1400>

14. Kühleis DC. Epidemiologia da tuberculose em uma penitenciária do Rio Grande do Sul [dissertação]. Porto Alegre: Universidade Federal do Rio Grande do Sul; 2013. Availablefrom: $<$ https://www. lume.ufrgs.br/bitstream/handle/10183/78088/000884195. pdf? sequence $=1$

15. Silva ACO. et al. Tratamento supervisionado no controle da tuberculose: potencialidades e fragilidades na percepção do enfermeiro. Rev Eletrônica Enfermagem [Internet]. 2007 [cited 2016 Nov 21]: 9(2): 402-416. Available from: https://www.fen. ufg.br/fen_revista/v9/n2/pdf/v9n2a09.pdf

16. Oliveira VAS, Guimarães, SJ. Saúde atrás das grades: o Plano Nacional de Saúde no sistema penitenciário nos estados de Minas Gerais e Piauí. Saúde em Debate [Internet]. 2011 [cited 2016 Nov 21]; 35 (91): 597-606. Available from: <http://www.bioetica. org.br/acervo biblioteca/revistas/artigo.php?codigo=26568>

17. Castro VD de. Saúde nas prisões: um estudo da implementação do programa de controle da tuberculose em uma unidade do sistema penitenciário [dissertação de mestrado]. Rio de Janeiro: Escola Nacional de Saúde Pública Sergio Arouca; 2011.

18. Oliveira HB, Moreira Filho DC. Abandono de tratamento e recidiva da tuberculose: aspectos de episódios prévios, Campinas, SP, Brasil, 1993-1994. Rev Saúde Pública [Internet]. 2000 [cited 2016 Nov 21]: 34 (5): 437-43. Available from: <http://www.scielo. br/scielo.php?pid=S0034-89102000000500002\&script=sci abstract\&tlng=pt>

\section{Publish in International Archives of Medicine}

International Archives of Medicine is an open access journal publishing articles encompassing all aspects of medical science and clinical practice. IAM is considered a megajournal with independent sections on all areas of medicine. IAM is a really international journal with authors and board members from all around the world. The journal is widely indexed and classified Q2 in category Medicine. 